\title{
Electric Cars Reach Maturity
}

\section{Dear Reader,}

The electric car industry is beginning to reap the benefits of its hard work. Many models with an "e" in the name are now available from manufacturers in Germany and in countries all over the world. The next step is for the German domestic market to get off the ground.

Despite all the prophecies of doom, German politicians and car manufacturers have chosen to focus on this powerful, low-emission means of transport, which will be the only means of providing environmentally friendly personal mobility in future. Even though the German coalition agreement of 2013 stated that the new government would support the growth of the electric vehicle market by offering "incentives for users instead of purchase subsidies”, Angela Merkel has now introduced a subsidy program in Germany. Buyers receive a 4000-euro discount on electric cars and 3000 euros for a plug-in hybrid. Whether or not you are in favour of the subsidy, you will doubtless agree that it has come very late in the day. However, it will still have an impact because it will be featured in the media as well as providing financial assistance for buyers.

The success of the new measure can easily be evaluated. In 2015 only $0.7 \%$ of new vehicles registered in Germany were electric cars, while in the Netherlands the figure was $10 \%$ and in Norway $23 \%$, because the infrastructure in these countries is widely established. Thanks to the subsidy, 936 German buyers had opted for electric vehicles by 14 July and 1523 by 29 July. If the charging infrastructure is extended in Germany, the growth rate should increase even further. There are already plenty of attractive electric cars and plug-in hybrids on the market which are suitable for everyday use. These include the Audi A3 e-tron, BMW i3 and VW eGolf, as well as the models which have proved to be most popular over the last four years such as the Renault Zoe and Nissan Leaf. In addition, Hyundai will soon be offering the Ioniq plug-in hybrid saloon and Kia will be launching the Niro, its SUV equivalent. In June, Henning Kagermann, Chair of the German National Platform for Electric Mobility (NPE) in Berlin said: "The question is not whether electric transport is coming, but how well we in Germany are prepared for it." The NPE needs to complete its research and development road maps.

You could say in response that despite all the $R \& D$ results that have been produced in so-called shop windows over the last five years, what is needed for sustainable market growth is an incentive system with subsidies, marketing and trade, which would allow the research results to be turned into reality. In this context, Franz Loogen, Managing Director of E-Mobil BW, has called for "fewer objectors and short-term profitmakers and instead more people who have the courage to act in a commercial context". The fruit is not only ripening on the tree, but also being eaten. Technical developments will ensure that we have a harvest in the years to come. You can find out more about these in the cover story of this issue, which looks in depth at battery and fuel cell technology.

Best wishes,

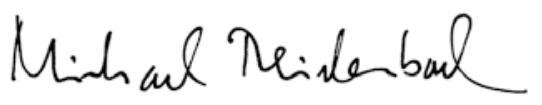

Dipl.-Ing. Michael Reichenbach Deputy Editor in Chief

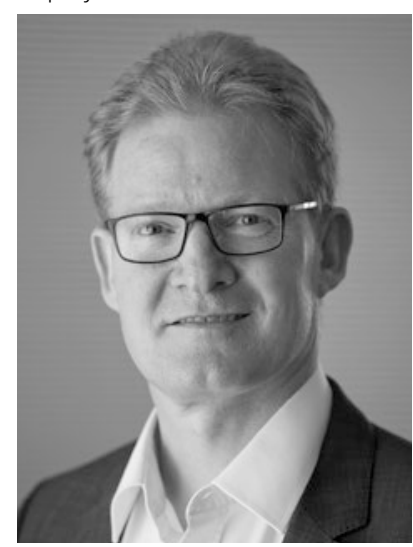

